\title{
REMOTE OPERATIONS IN A FUSION ENGINEERING RESEARCH FACILITY (FERF)
}

James N. Doggett

March 14, 1975

\section{MASTE:}

Prepared for U.S. Energy Rescurch \& Development

Administration under contract No. W-7405-Eng-48

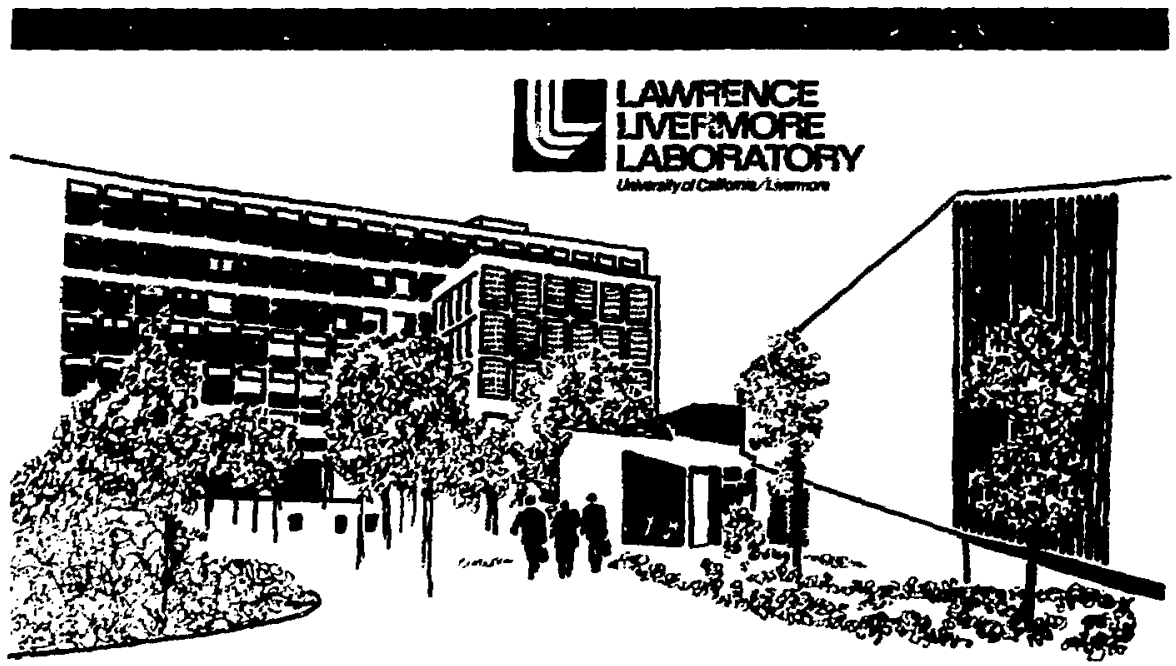


NOTICE

TTh report we prepured w en ecount of work

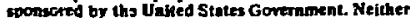
the United Stutes oor the United Stutel Enerty Reverch \& Dewlopment Adnintatration, not any of their employecs, not any of their costractors.

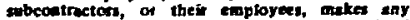

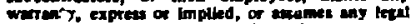
lindity of responsbility for the accuracy. conplettones or uefulines of any inforeaticn. eppertus, prodtect of proctos dienoed of copresents that its an would not infringe pitrueb-owned riste"

Printed in the United States of America Available from

National Technical Information Service

U.S. Department of Commerce 5285 Port Royal Road

Springfield, Virginia 22151

Price: Printed Copy \$ \$; Microfishe $\$ 2.25$

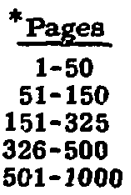

NTIS

Selling Price

$\$ 4.00$

$\$ 5.45$

$\$ 7.60$

$\$ 10.60$

$\$ 13.60$ 
TID-4500, UC-20

Controlled Thermonuclear Procesged and

Flasma Phyaics

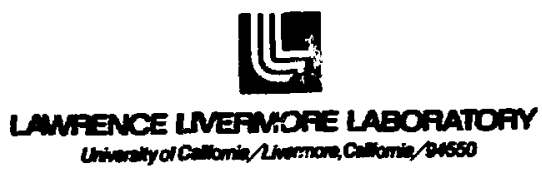

UCRL-51778

\section{REMOTE OPERATIONS IN A FUSION ENGINEERUNG RESEARCH FACULTY (FERF) \\ James N. Doggett}

MS, date: March 14, 1975

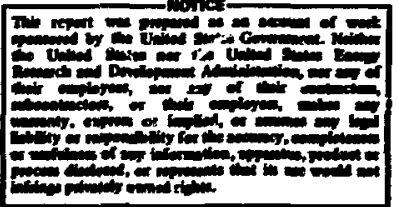

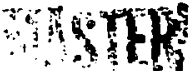




\section{Contents}

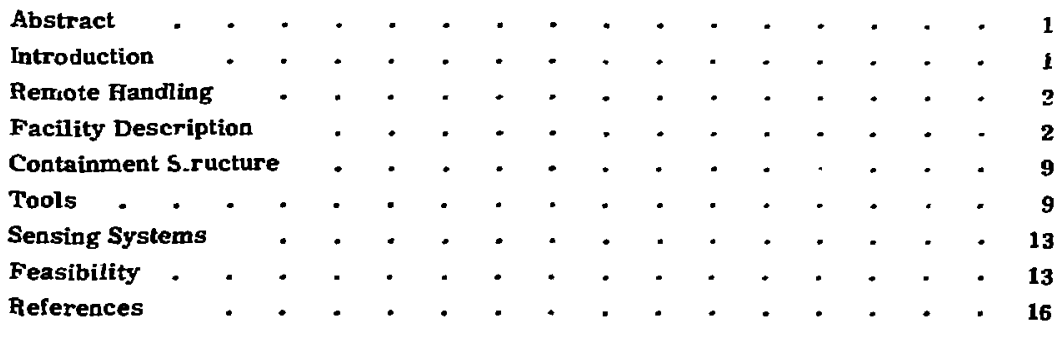




\title{
REMO'TE OPERATIONS IN A FUSION ENGINEERING RESEARCH FACILITY (FERF)
}

\begin{abstract}
The proposed Fusion Engineering Research Facility (FERF) has been designed for the test and evaluation of materials that will be exposed to the hostile radiation environment created by fusion reactors. Because the FERF itself must create a very hostile radiation environment, extensive remote handling procedures will be required as part of its routine operations as well as

for both scheduled and unscheduled ruaintenance. This report analyzes the remote-handling implicatione of a vertical- rather than horizontal-orientation of the FERF magnet, describes the specific remote-handling facilities of the proposed FERF : rtallation and compares the FERF remote-handling sysiem with several other existing and proposed facilities.
\end{abstract}

\section{Introduction}

The Fusion Engineering Research Facility (FERF) is a small mirror-fusion reactor. Its purpose is to prcvide an intense source of $14 \mathrm{MeV}$ neutrons for use in materials- and component-studies applicable to fusion-power-reactor resign. The total-source strength will be $10^{18}$ neutrons/s with a fux in the test region of $10^{18}$ iteutrons $/ \mathrm{m}^{2} \cdot \mathrm{s}$. (Ref. 1) FERF requires extensive remote-handling facil ities because of the hostile radiation environment present throughout its containment volcme. Hazards Include a high neutronand gamma-flux during operation, high gamma-flux after shutdown, tritium contaminution and a nitrogen atmosphere. After machine shutdown, the gamma field in the reactor vault will be too intense to allow entrance by an unshielded person, requiring all maintenance and repair to be done remotely. This requirement influences the design to the extent that all equipment in the vault and all systems passing through the walls must be easily accessible and designed for remote maintenance and operation. 'The radiation field has the additional effect of limiting the list of materials available for use in the system to those sufficien: radiation resistant to provide acceptably long operating lives.

The purpose of this report is to describe the impact of the proposed FERF facility design on the problem of remote handling. Included in a discussion of required remote-handling tools and sensing systems as woll as a dipaussion of the feasibility of the proposed remote-handling configuration. Many of the concepts and techniques discussed in this report were originally described in Ref. 1, which should be consulted if further information is desired. 


\section{Romote Handling}

Remote hardline includes any operation theth for safety or logiatical reasons. does not allow direct human contact with the composents being tundled. Under this definition, "remote handing" ranges from, ay, the household use of a fire poker to the ground control of a space probe. As the "remotu:nese" incresses, the availability of direct hman sensory feedbuck diminishes. The lack of direct senoing by the operator does not rule out ccmplex operations, but does greally increase their cost in time and equipment. It is estimated that bot-cell type remote operations take 4 to 20 times an long a the same job done in a direct-contact mode. 2 Even where a "suited up" worker can do direct operations, there is a multiplication of required manpower by a factor of 3 to 5 (Rer.3) mainly in proper adminiatmation of safe operations.

Clearly, the requirement for remote hendling will have a significant impact on the design and cost of thia racility. To minimize this impact, the number of components subject to remote handling must be as small as practical, and the "in-vault" componente must to simple, reliable and accessible. In addition. adequate remote tooling and careful plarnings of maintenance and repatr activities must be provided.
For a machine like FERF, remote etivities can be divided into three categories, each having implications for the design process. The categories are:

- Remote Operations. This include. those functions normally involved in remote control, e. L., valve operation, controd adjustments and diagnostics. These remote functions are required to actually operate the machine. They are highly specialized and obviously must be bighly reliable.

- Scheduled Maintenance. This includes planned replacement or repair of unite having a known, limited sperating life. These are repetitive operations that justify extensive apecial touling to minimize their totai cost uver the life of the machine.

- Unscheduled Repair. This category includes repair or replacemeat of components suffering unanticipated failure. This clase of operation is handled by generai-purpose sooling. The costs of this type of operation can be kept down by careful desiga of components in order to make them compatible with the remote tooling avallable.

\section{Facility Description}

The facility described here differs fro.7 that described in the previous FERF proposal ${ }^{1}$ in that the reactor axls is vertlcal rather than norkzontal. This approach was chosen for the follo: ing reasons:

1. The magnet ayatem is utructurally atable when assembled with its 
axis vertical. In the vertical position it requires a minimum of supporting structure.

2. A vertical magnet-orientation simplifies the handling of the most frequently replaced components.

3. A vertically mounted reactor is located symmetrically within the operating vault. This simplifies the connection scheme, maximizes the standardization of parts and reduces the number of different types of remote-handling operations. The magnet system $i$ s shown in Figs. 1 and 2. While the total gravitational load of about 1500 tonnes requires a substantial supporting structure, this is a small force compared to the caliulatid 35,000-tonne attractive-force between coils. In a horizoncal magnet configuration, a heavy supporting structure is required to sustain both the gravitational loads and the attractive forces, Hut with a vertical assemoly of the magnet system, a reduction in structure can result because the gratitational loads are coaxial with the attractive force. Therefore, the gravitational load can be easily transmitted to the base of the inagnet systcm by the same structure that handles the attractive force.

The nagnet system is a simple stack of components; that, at any stag* of asstmbly, witl stand alone without auxiltary support. The simplicity of this assembiy eliminates the med for much of the supporting structure required for a horizontal assembly. It is assumed in this design that the magnet assembly will not be anoved fo1" the life of the coila and that no attempt wili be made to repair failures internal to the coil cases.
The four injectors, Figs, 3 and 4, are the largest components that will be on $a$ regular replacement schedule. They are approximately 2 in square, weigh 25 tonnes, and are scheduled for replacement every 6 months (one injector every 6 weeks). With vertical assembly, the four injectors are located near the midplane of the operating vault, thus raking them readily accessible to manipulators and handling fixtures. Other orientations of the reactor place at least one injector in a difficult position for replacement operations. The symmetrical positioning of the reactor axis in the operating vault favor: stancardication of injector mechanical- and elestrical-connections. This not only reduces the spares and special-tooling inventory but reduces the number of different remote operations that will be required for maintenance. The operational availability of the facility will be largely controlled by the dow $n$ time necessary for injector replacement. Therefore, operational- or designsimplifications that reduce the difficulty in handling the injectors will have a direct impact on the effectiveness of th facility.

The most massive components to be handled remotely during the useful life of the reactor will be the two 50-tonne expansion-tank assemblieg (Fig. 5) which include the first-wall sections. The first wall $w$ ill be replaced $w$ hen it has detertorated to its safe-operating limit (estimated period: 2 years). The expansiontank asscmblies form reentrant sections that penetrate to the center-line of the machine. Although these assemblies could be inserted in a horizontal reastor. the long cantelivered first-wall and shicld 


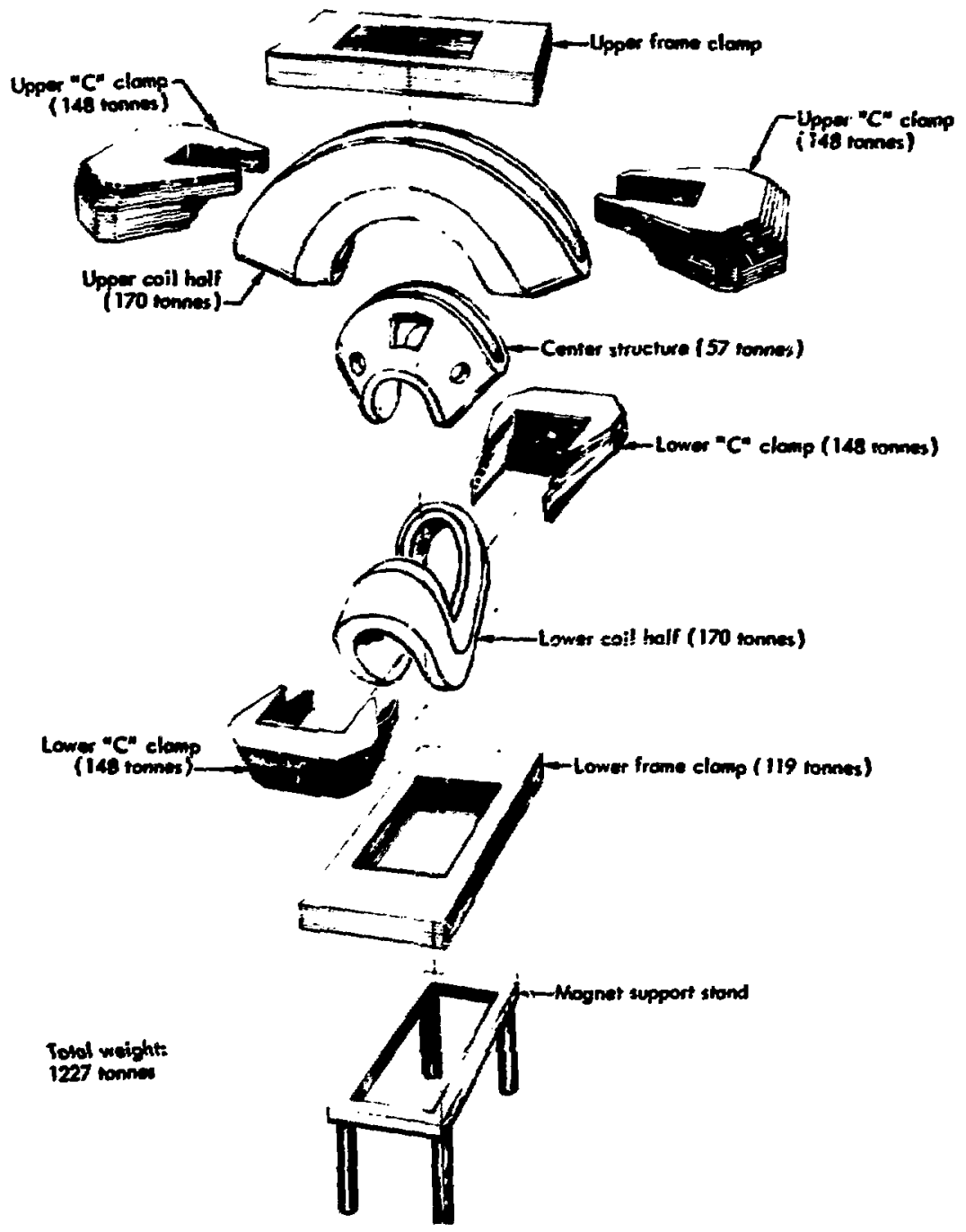

Fis-1. Magnet system components. 


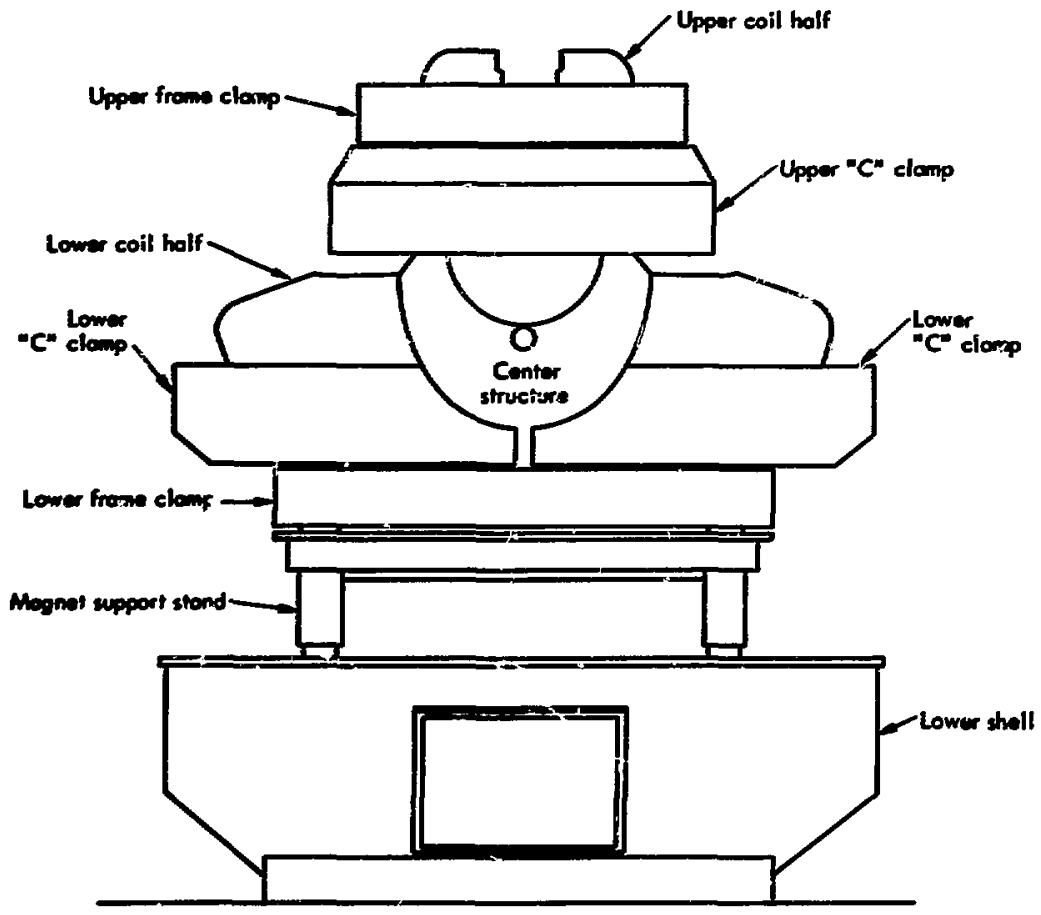

Fig. 2. Assembled magnet system. 


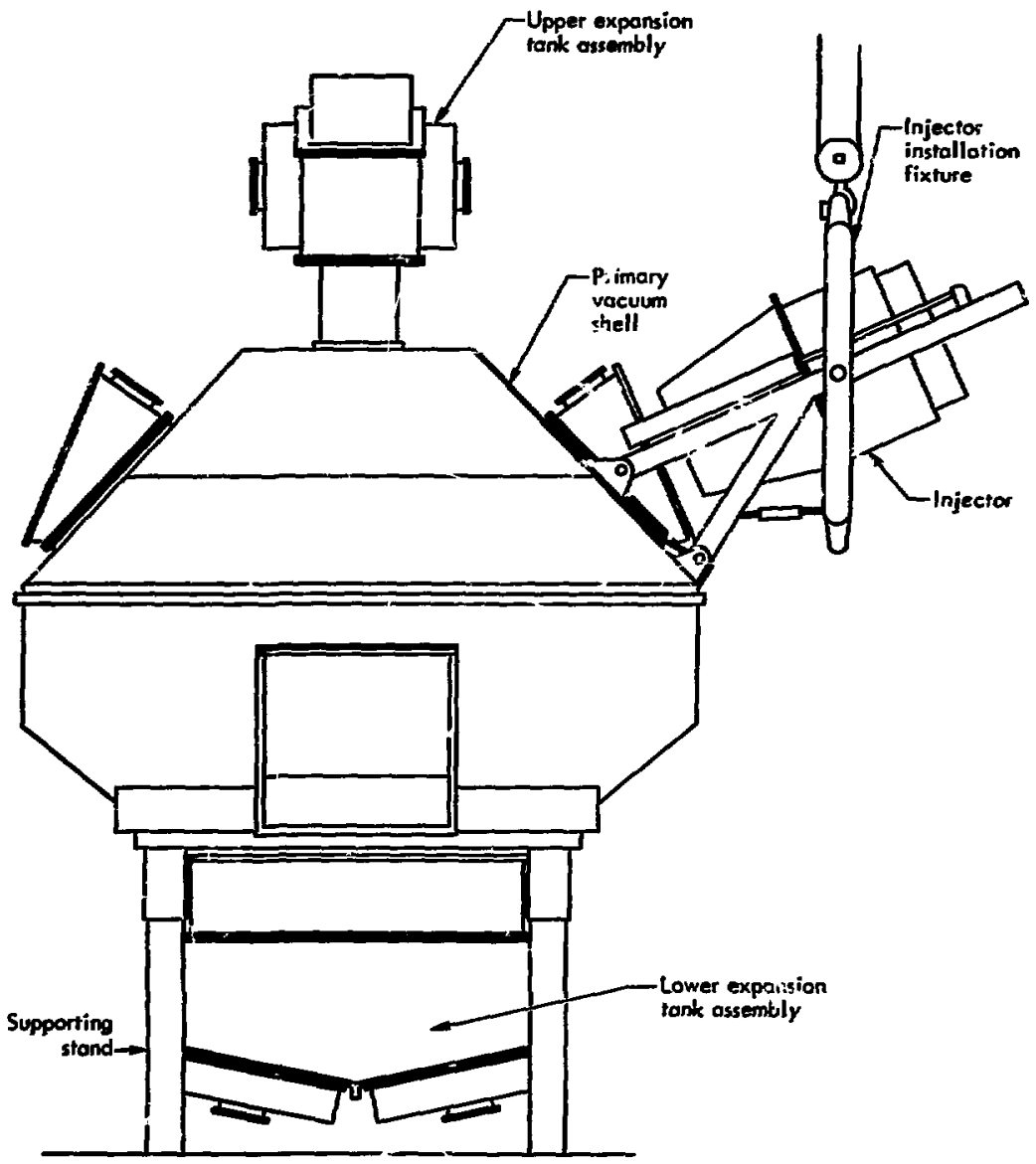

Fig. 3. Injector installation and removal. 


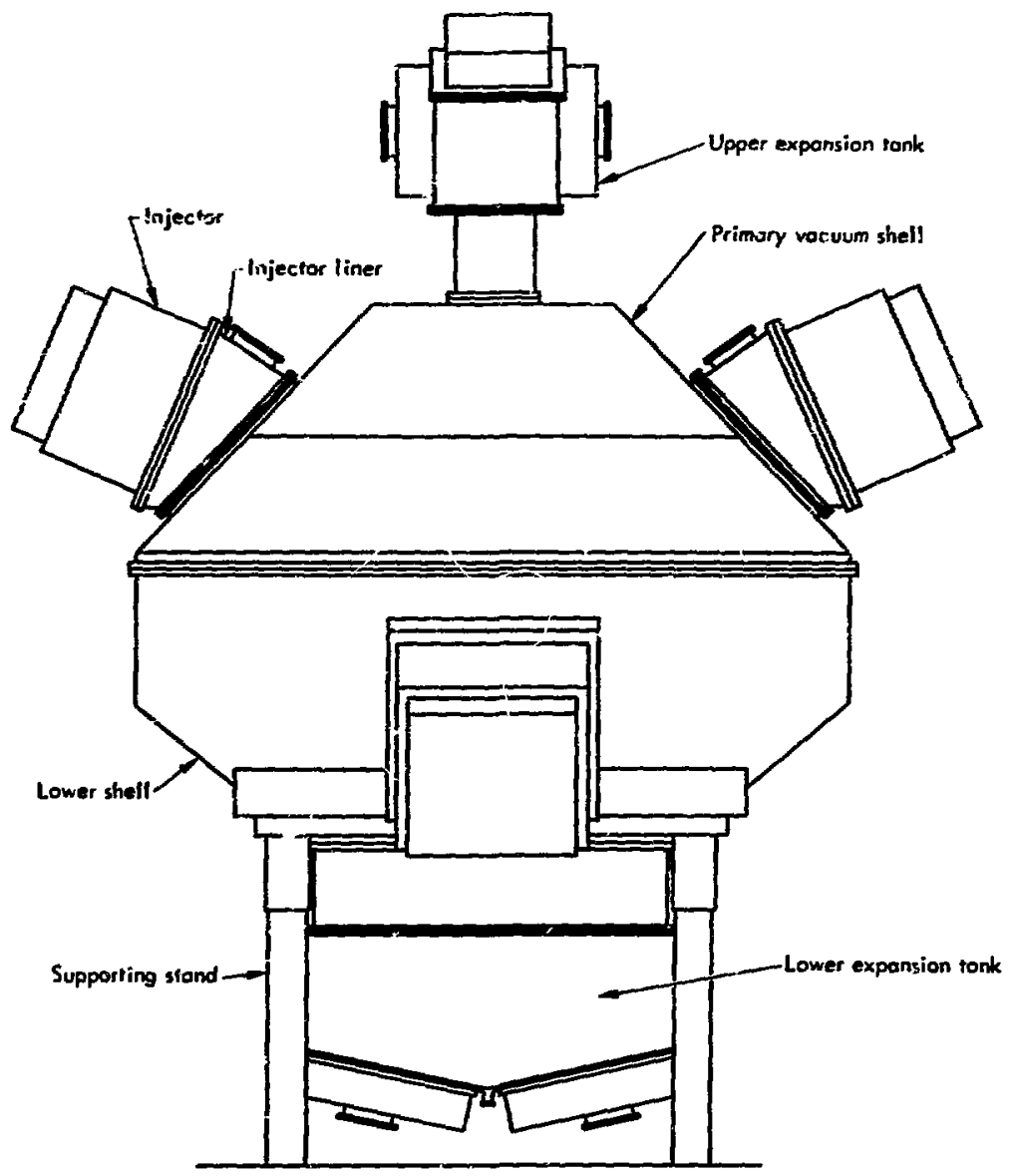

- Vig. 4. Machine assembly showing injectors in piace. 


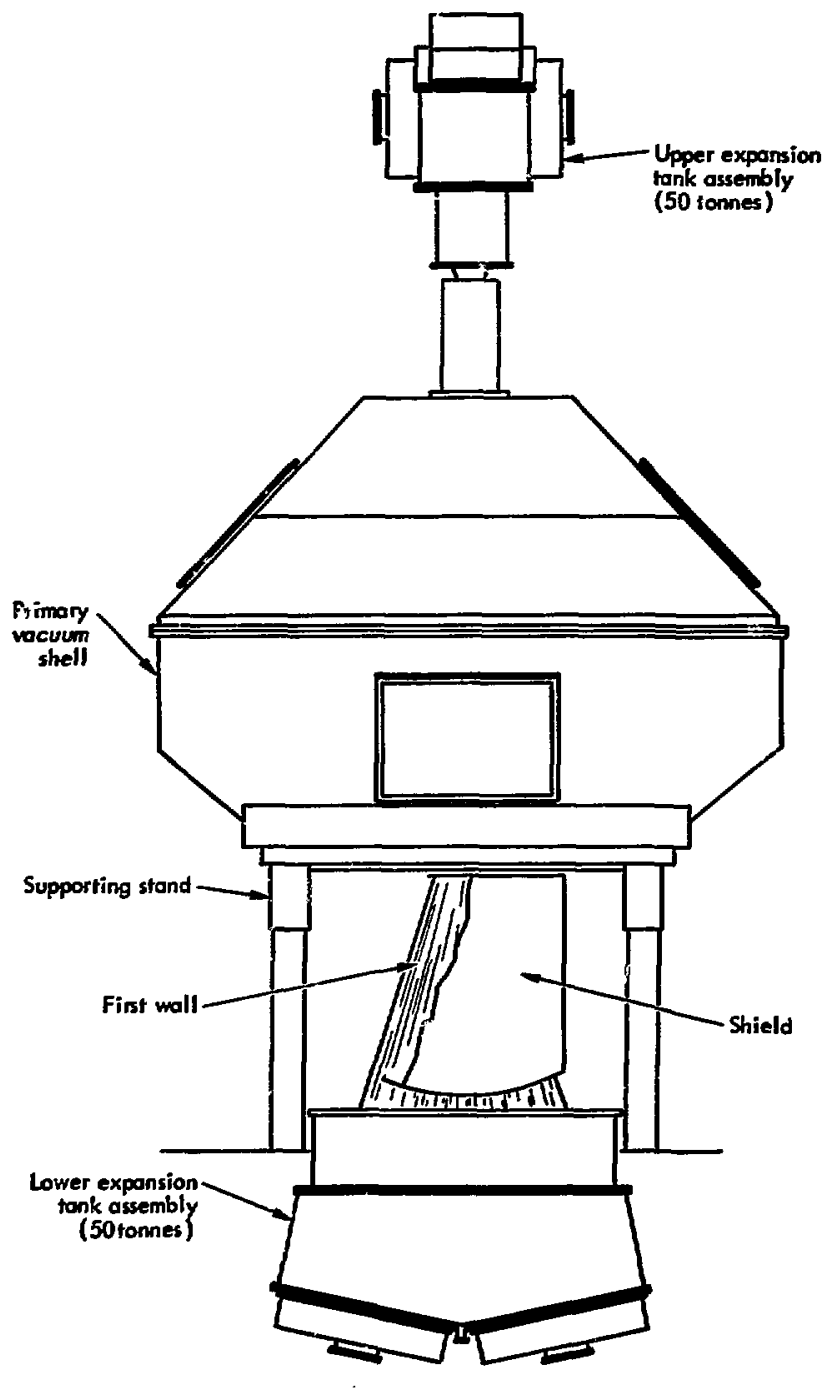

Fig. 5. Insertion and removal of lower expansion tank assembly. 
portions of a horizontal system require highly precise control during assembly. This precise control is much more readily obtalned with the free-standing or free-hanging assembly of a vertically oriented system.

\section{Containment Struature}

This discussion of the containment structure is limited to the biologicallyshielded area since this is the basic area involved in remote operations. The shielded area (Figs, 6 and 7 ) is divided into two major areas: the operating vault and the hot-maintenance shops. The operating vault is $22 \times 22 \times 27 \mathrm{~m}$ high, has $3-m$-thick concrete walls and ceiling and is sealed with a metal membrane. Penetrations are provided for windows, vtilitles, experimental facilities, controls and equipment access. The machine stands in the center of the rcora. Connections to the machine are grouped to minimize remote operations during routine maintenance. For example, when an injector is replaced, only those services directly connected with that injector need be handled. The vault opens into the hot maintenance shop through a $3 \times 22 \times 15-\mathrm{m}$ high main-shield donr. The door size is diclated by the need to remove the overhead crane and manipulators from the vault during machine operation in order to prevent their activation by neutrons.
The main hot maintenance shop is $22 \times 24 \times 15 \mathrm{~m}$ high. The walls, ceiling, and floor are made of concrete and are sealed with a metal membrane contiguous with that of the operating vault, Adjoining the main hot shop are specialized hot cells, a storage area, and the main air lock. The hot-maintenance areas will be tooled for doing both routine and extraordinary maintenance and repair. The main bay will be equipped with general-purpose gear such as large manipulators, welding equipment, leakchecking instruments, and small tools. The hot cells will have specialized tooling for such jobs as injector rebuilding and test, and post-operational component inspection. The hot-maintenance shops will include a large storage area where activated or contaminated parts can be safely and conveniently stored until they reach a quantity sufficient to warrant operating the air lock. The main hotshop and the hot cells will be decontaminatable to the extent that a suited operator with breathing apparatus may enter to do direct maintenance.

\section{Tools}

The major tools necessary for FERF remote operations consist of a 228 tonnetotal-capacity overhead crane and three large manipulators. The crane, a double 11-tonne-capacity unit with a 9-tonne auxiliary, serves both the hot shop and the operating vault. It will be equipped with a motorized rotating hook as well as mechanisms to allow retrieval in case of fallure while in the operating vault, One 


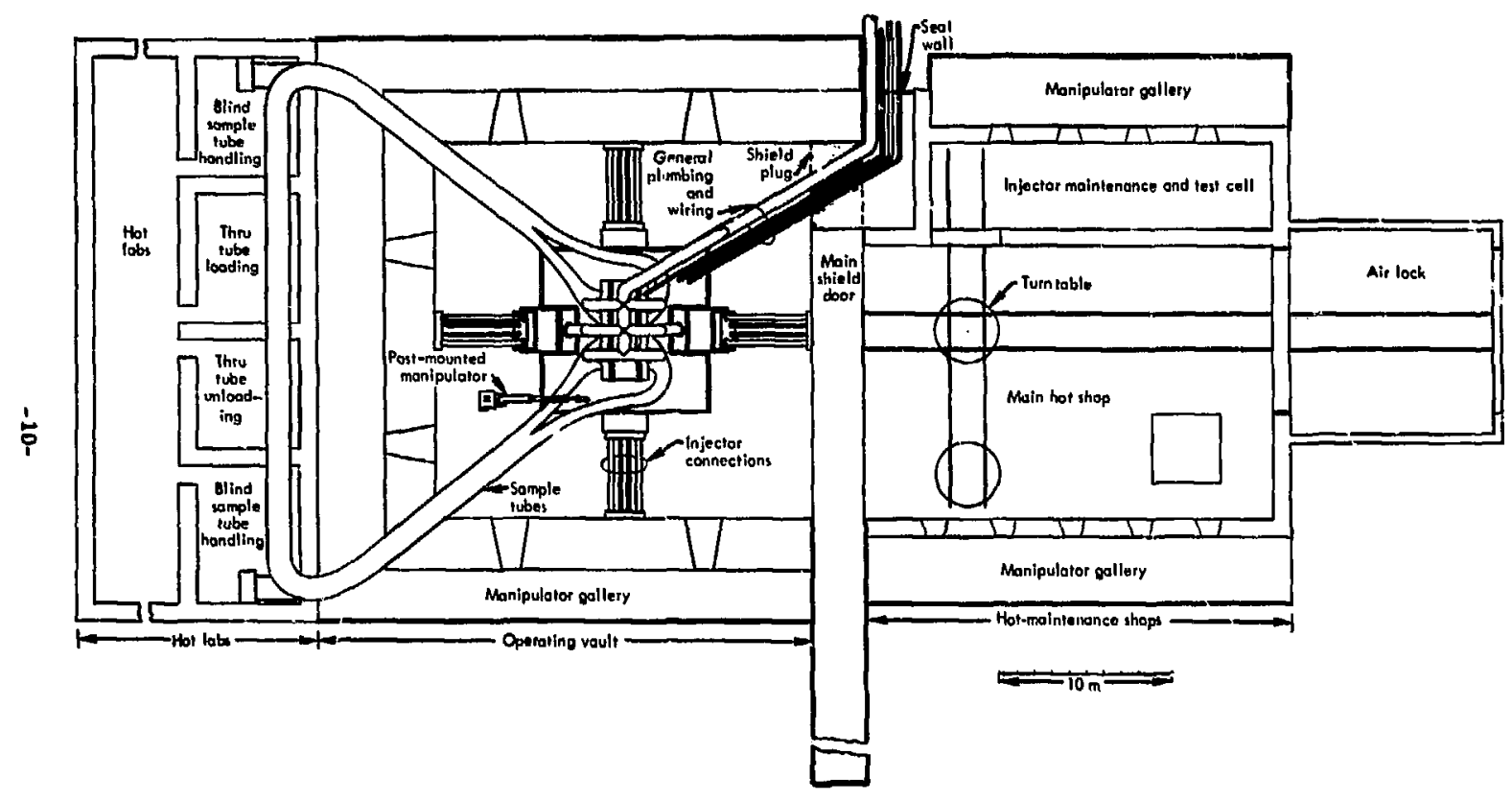

Fig. 6. FERF installation layout - plan vlew. 


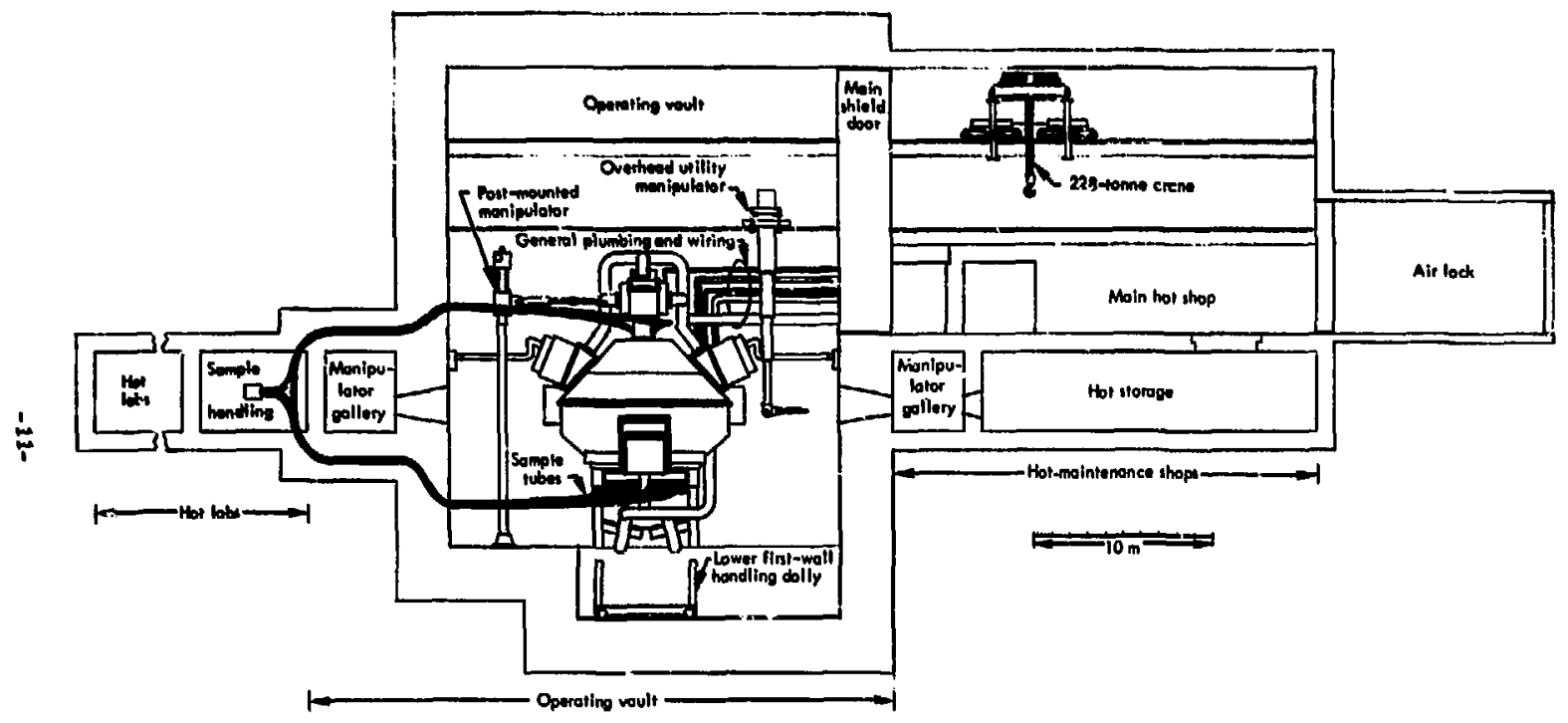

Fig. 7. FERF installation layout - elevation view. 

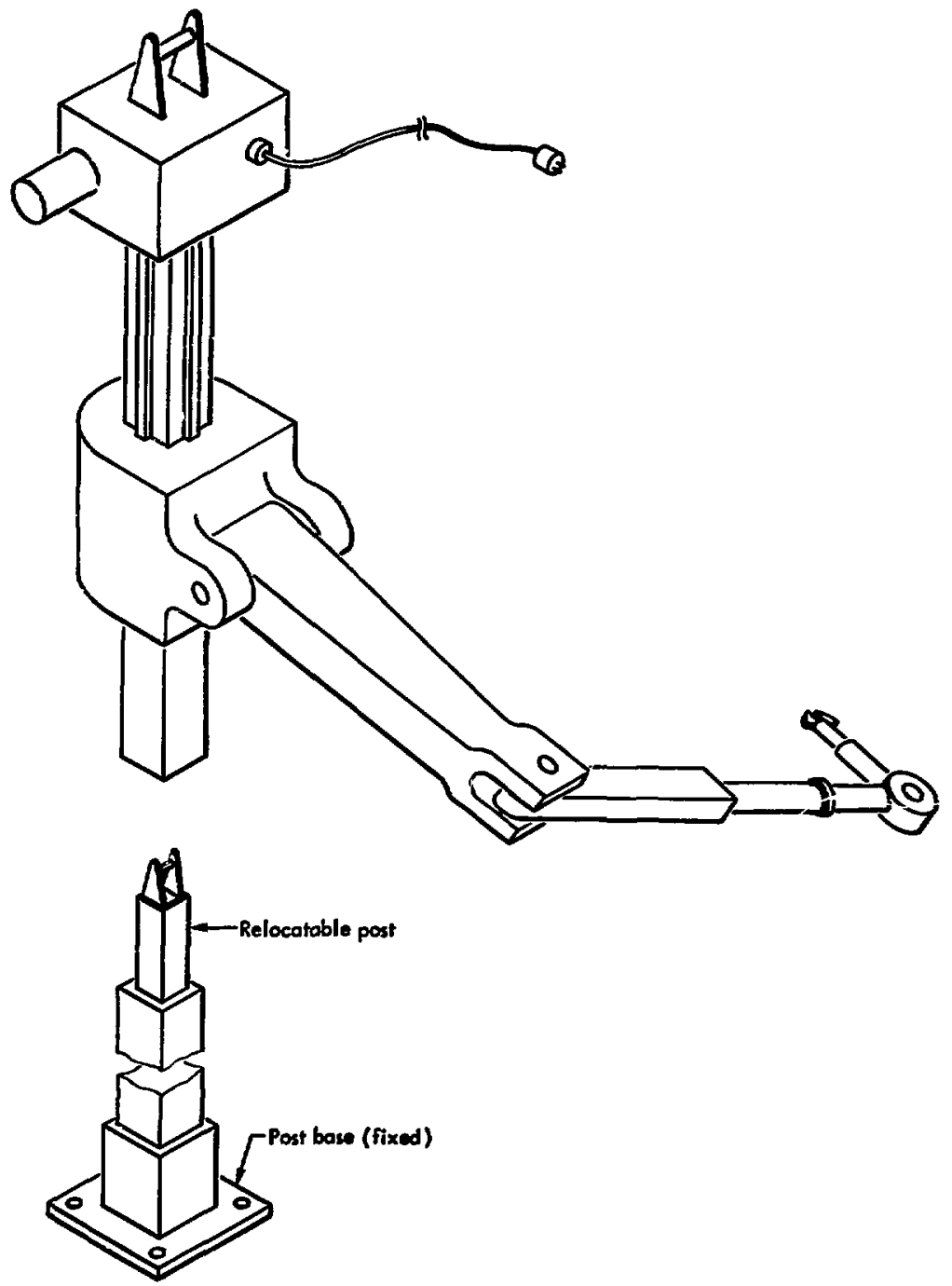

Fig. 8. Relocatable post-mounted manipulator. 
of the large manipulators is an overhead type that travels on a bridge trciley below the overlead crane. It can reach the ceiling and the top half of the machine. Its purpose is to do light work such as assisting crane hrokups, electrical connections, or lighting waintenance. The other two manipulators (Fig. 8) are mounted on posts adjacent to the machine. These two are the main-disassembly tools for heavy maintenance and repair op- erations, Each has a 6-m reach, a $\mathbf{2 8 2}$ kg-irorizontal-load capability, and can traverse the full height of the machine. In order to give full room-coverage, the manipulator mounting post $\mathrm{s}$ can be moved to many alternate positions, as shown in Fig. 9. As with the overbead manipulator, these units are removed to the main hot shop during machine operation and are available there for remote work.

\section{Sensing Systems}

Sensing systems, which provide operators of remote-harilling equipment visual-, "feel"-. and aural-feedback, will be . equired for both operation and maintenance. Listed in order of importance, the senses used in remote operations are vision, force-feedback (or "feel"), and then sound, Windows for direct vieving, binoculars, telescopes and periscopes form the primary visual system. Extensive use of fixed and rabile television will augment direct vision for viewing obstructed areas or for close-in work.
Large, overhead manipulators do not normally provide force feedback (i. e. "feel"). However, some heavy-duty industrial maripulators and some remote mastcr/slave manipulators with force feedback are commercially available. For operations requiring "feel," this kind or 'eedback will be provided, either by means of some specific motions of the large manipulator or by using a smaller master!slave unit as an accessory.

\section{Fensibility}

In cvaluating the feasibility of the proposed FEHF remote-handting aystcm, it is useful to compare it with orther remute operations of comparable atz: anri complexily. Tabie 1 compares groks dimenatons and handhing capablitiles or fowr facilltice: (I) Fillt: (2l the proponed Two-Component-Torun (TCT) system, (3) Aircraft-Nurlear-3rcousaton (AVI) Hot shop, and (f) thr lingine Mlotntenence and Cheasnembly building (E-MiAt)). TC $T^{t}$ and FEHF are in the preliminaryplanning and conceptual stages. The AXP Hol shop" and b-MAD ${ }^{5}$ were bulle in the 1960's and are presently operated in a sandby- or minor-usage mode. Frikt tw whintly larker than ang of the oltwr threc tactlite's, It requirse : higher capacily crane, and itw manipulator* will have ercalor vertical Iravel. from a 


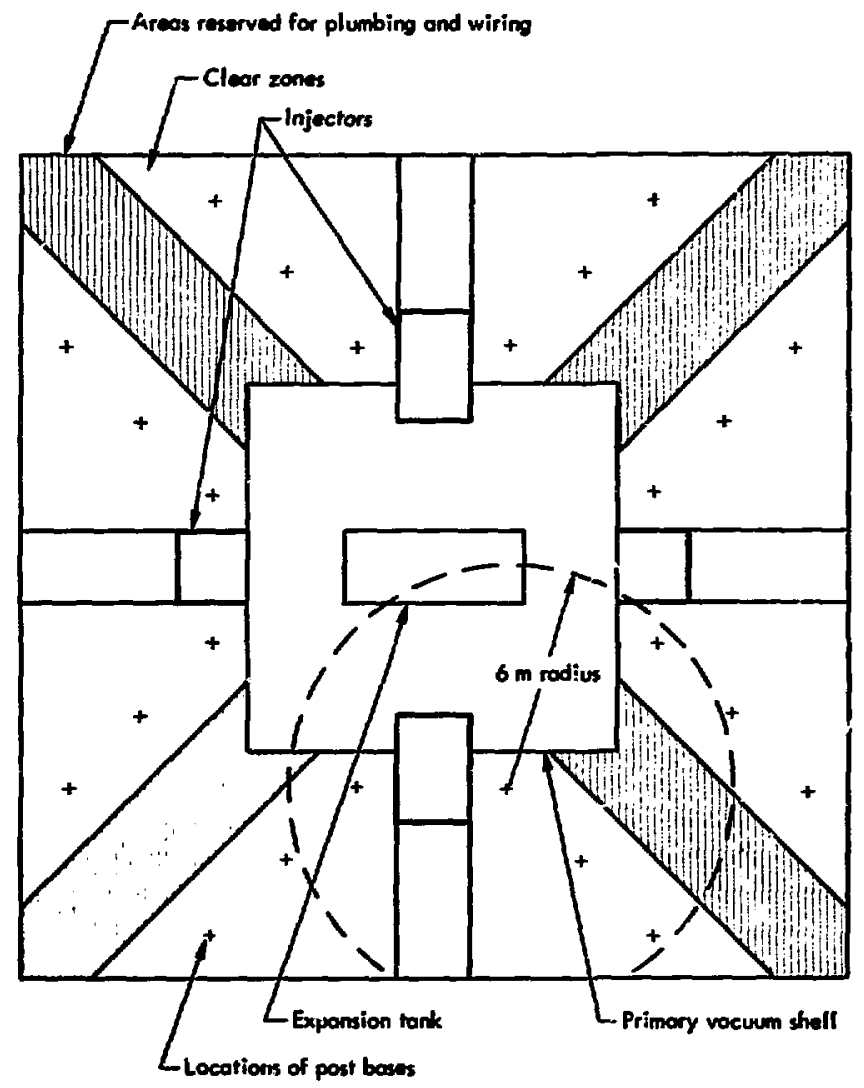

Fls. 9. Plan view of operating vault, shroving locations of bases for post-mounted relocatable manipulators. Each manipulator can operate through a $6 \mathrm{~m}$ radius.

ceometrical atandpoint, FERF is well whin the capabiltties of present-day remote-handline equipment technology.

From the standpoint of complexity of operations, comparisons between these systemn become leas clear. The remote hundling to be done is the operating vault of frift in lese complicated than that performed in many hot-cell installations. However, the parts to be handled by the FEiRF system are numerous, large, and hea $r y$. With respect to weight, componenira no heavier than 18 tonnes have been haniled remotely in elther the ANP Bot Shop or E-MAD. However, in normal malntenance the heaviest FERF part to 
be handled remotely will weigh 50 tonnes and will be more complex and more delicate than those of the other systems.

Making and breaking fluid, electrical and mechanical connections comprise the majo-ity of the remote-handling tasks in the FERF operating vault. There is ample evicance from many gears of hotcell work that nuid, electrical, and mechanical connections of the kind and quality required by FERF can be remotaly handled aucce afully. Extensive development and test of the specific connectors for FERF will] tequired in order to optimize handing operations. The more complicated maintenance and repair will be done in the hot shop and adjacert hot cells. These areas $w$ ill be equ'pped with conventional master/slave malipulators abd special tooling to facilitate work that is more difficult and delicate than can be done in the operating vault.

Table 1. Comparison of remote-handling capabilities of four facilities.

\begin{tabular}{|c|c|c|c|c|c|c|c|}
\hline \multirow{2}{*}{$\frac{\text { Parameter }}{\text { Vaut/sinop dimensions: }}$} & \multicolumn{2}{|c|}{$\begin{array}{l}\text { FERF } \\
\text { proposal }\end{array}$} & \multicolumn{2}{|c|}{$\underset{\text { proposal }}{\text { TCT }}$} & \multicolumn{2}{|c|}{$\begin{array}{l}\text { ANP } 2 \\
\text { hot shop }\end{array}$} & $E-M A D^{5}$ \\
\hline & Vault & Shop & \multirow{2}{*}{\multicolumn{2}{|c|}{33}} & \multirow{2}{*}{\multicolumn{2}{|c|}{49}} & \\
\hline Length (m) & 22 & 24 & & & & & 44 \\
\hline Width (m) & 22 & 22 & \multicolumn{2}{|l|}{31} & \multicolumn{2}{|l|}{15} & 20 \\
\hline Height (m) & 27 & 15 & \multicolumn{2}{|l|}{16} & \multicolumn{2}{|l|}{15} & 21 \\
\hline Total volume $\left(\mathrm{m}^{3}\right)$ & \multicolumn{2}{|c|}{21318} & \multicolumn{2}{|c|}{16368} & \multicolumn{2}{|c|}{11025} & 18400 \\
\hline \multicolumn{8}{|l|}{ Bridge-crane capacity } \\
\hline Primary/aux. (tonnes) & \multicolumn{2}{|c|}{$114,114 / 9$} & \multicolumn{2}{|l|}{$91 / 9$} & \multicolumn{2}{|c|}{$91 / 9$} & $36 / 9$ \\
\hline $\begin{array}{l}\text { Number of overhead } \\
\text { manipulators }\end{array}$ & \multicolumn{2}{|l|}{1} & \multicolumn{2}{|l|}{1} & \multicolumn{2}{|l|}{1} & 1 \\
\hline Travel $L \times W \times H(m)$ & \multicolumn{2}{|c|}{$40 \times 20 \times 10$} & \multicolumn{2}{|c|}{$20 \times 28 \times 7$} & \multicolumn{2}{|c|}{$46 \times 11 \times 7$} & $37 \times 15 \times 12$ \\
\hline Arm reach (m) & \multicolumn{2}{|l|}{6} & \multicolumn{2}{|c|}{3} & \multicolumn{2}{|c|}{2.1} & - \\
\hline Hand load capacity (kg) & \multicolumn{2}{|l|}{ 18: } & \multicolumn{2}{|l|}{181} & \multicolumn{2}{|l|}{227} & - \\
\hline Side-wall manipulators & \multicolumn{2}{|l|}{2} & 1 & 2 & 2 & 1 & 2 \\
\hline Travel $\perp \times$ H (m) & \multicolumn{2}{|l|}{$0 \times 16$} & $24 \times 6.5$ & $0 \times 5.1$ & $46 \times 6.7$ & $46 \times 4.6$ & $37 \times 6$ \\
\hline Arm reach (m) & \multicolumn{2}{|l|}{6} & 9.7 & 6 & 5.7 & 7 & 10 \\
\hline Hand load capacity (kg) & \multicolumn{2}{|l|}{181} & 181 & 181 & 18 & 18 & 272 \\
\hline
\end{tabular}




\section{References}

1. T. H. Batzer et al., Conceptual Design of a Mirror Reactor for a Fusion Engineer: ing Research Facility (FERF), Lawrence Livermore Laboratory, Rept, UCRL51617 (1974).

2. D. C. Layman and G. Thornton, Remote Haindling of Mobile Nuclear Systems, U. S. Atomic Energy Commission, Division of Techrical Information, Rept. TID-21719 (1966).

3. A. B. Ritchie, Safety Experience and the Control of Hazards in the frot Cell Operations at Harwell, Proc. Conf. Remote Syst. Tech., 15th, Chicago, 1967 (American Nuclear Society, Hinsdale, IL, 1967), p. 176.

4. J. French, Westir thouse E]ectric Corp., Research and Development Division, Pittsburgh, PA, private communication, November 1974.

5. R. E. Schaffstall and L. E. White, Preparing for Disassembly Querations of Nuclear Enpine Hardware, Proc. Conf. Remote Syst. Tech, 15th. Chicago, 106: (American Nuclear Society, Finsdale, IL, 1967), pp. 134-140. 